\title{
Activities of Women and Men Village Representatives in Poland: A Comparative Gendered Analysis ${ }^{1}$
}

\author{
llona Matysiak
}

\begin{abstract}
The main aim of this article is to analyze whether women and men differ in performing the role of village representative - do they express differences in leadership style, have different ideas for local initiatives, and different ways of cooperating with other local actors? If yes, the question is how these gender differences could be adequately explained. The theoretical framework draws from the literature on the substantive representation of women in politics as well as findings about gender differences in leadership style. The analysis of empirical data presented in the article indicates that the differences in the modes of working of women and men village representatives are minor and that social role theory is the most adequate explanation. It is also argued that contextual factors such as the presence or absence of other women in the local public sphere play a crucial role.
\end{abstract}

KEY WORDS gender, village representatives, rural areas, local politics, substantial representation, leadership style

\section{Introduction}

The function of a village representative (soltys) in Poland is as liaison between the village residents and higher levels of local authorities. In the last few decades the number of rural women serving as village representatives has increased significantly. In 1958, the percentage of female village representatives in Poland amounted only to $0.8 \%$ (Główny Urząd Statystyczny 1968), whereas in 2015, this percentage reached $39 \%$. $^{2}$ This increase provokes questions about the possible consequences of this process.

The main aim of this article is to analyze whether women and men differ in performing the role of a village representative - do they express differences in leadership style, have different ideas for local initiatives, and different ways of cooperating with other local actors? If yes, the question is then how these gender differences could be adequately explained by the influence of gender roles, or individual strategies of "doing gender" in various local settings? The function of a village representative is as part of the local government system in Poland and requires some elements of political leadership in order to represent

Sociální studia / Social Studies 4/2016. Pp. 27-44. ISSN 1214-813X.

1 This article contains an in-depth analysis of issues raised in the book based on the doctoral thesis, dedicated to the role of village representatives in modern rural communities in Poland (Matysiak 2014).

2 Główny Urząd Statystyczny, Local Data Bank (www.stat.gov.pl). 
residents' interests and negotiate them with local authorities and cooperate effectively with other local actors. Therefore, the literature on the substantive representation of women in politics, as well as gender differences in leadership style, is especially inspiring for this analysis. In addition, the characteristics of the local context, in terms of different levels of women's participation in local politics, will be of special interest. It is claimed that people construct their beliefs about the sexes on the basis of observations of the role performances of women and men (Eagly et al. 2012: 124).

The analysis presented in this article contributes greatly to on-going theoretical debates about gender differences in various aspects of life - their manifestations and adequate explanations, taking into account often confusing research results, in some cases indicating clear or minor differences, and no differences in others. The article contributes also to discussions on the political representation of women in rural areas in postcommunist countries which are peripheral in relation to Western countries. The predominance of traditional gendered norms and values seems to be particularly strong in these places. However, social changes often take place there spontaneously, in a manner which is not motivated or required by official pro-equality programmes or public policies (Bock 2014).

This article is based on a qualitative empirical study that covered ten municipalities located in different regions of Poland that are differentiated according to the presence of women in the local politics. First, details about the function of village representatives and rural women's participation in local government at the village level will be provided. The following sections discuss the study's theoretical inspirations and present the research problem as well as the methodology of analysis. The subsequent sections are devoted to the presentation of the empirical data.

\section{Village representatives in the local govemment}

The institution of the village representative (soltys) has a long and well-established tradition in Poland. It is rooted in the processes of settlement under German law in the Medieval Age. In the following historical periods, the obligations of village representatives and the nature of their role changed depending on political and economic conditions.

Poland is divided into sixteen provinces, several hundred districts and almost two and a half thousand municipalities. The latter are the strongest entities in the system in terms of the scope of responsibilities and financial independence. Municipalities located in rural areas (rural and urban-rural municipalities) are further divided into rural sub-municipal auxiliary units (solectwo) operating at the level of a village. ${ }^{3}$ According to the principle of decentralization, there are separate executive and legislative bodies at each level.

Village representatives are the executive officers of rural sub-municipal auxiliary units. The other institutions of these units include the village assembly (zebranie wiejskie) the legislative body - and a village council (rada sołecka) - the advisory body to the village

A rural sub-municipal auxiliary unit usually covers one village, but in some cases it may cover the territory of two small villages or a part of a larger village. 
representative. It has to be emphasized that, in terms of the structure of power, rural submunicipal auxiliary units are dependent both financially and institutionally on municipal authorities - they have neither their own full legal identity nor an independent budget. ${ }^{4}$

Village representatives and members of the village council are elected by the residents of the village. The election involves a secret, direct voting method, which mostly takes place at the village assembly. All residents can present themselves as a candidate for village representative or village council member. ${ }^{5}$ The term of office for the village representative is usually four years. It has to be noted that village representatives can participate in municipal council meetings, but they do not retain the right to vote. Four times a year, many village representatives collect local taxes from the residents of the village on behalf of the municipal authorities and receive the equivalent of a small percentage of the collected sum as a gratuity for their efforts (Matysiak 2014).

Basically, village representatives embody the interests of the residents and are expected to manage the daily problems of a given village, such as issues associated with the local infrastructure. They also perform administrative tasks, such as informing the residents about the local authorities' plans and decisions or organising village assemblies, and they are expected to mobilise the residents for collective initiatives. In fact, the scope of activities of the village representative differs from one municipality to the other, as these activities are not strictly defined by legal regulations, but rather become determined by the expectations and needs of the residents, the attitudes of particular municipal authorities, and the intentions of village representatives themselves.

Performing the role of village representative implies, to a greater or lesser extent, the elements of leadership. First of all, the function of a village representative is subject to election - thus, it can be expected that the elections are usually accompanied by political behaviours, associated with the building of support among the inhabitants or election competition. Secondly, female and male village representatives, as representatives of interests of the rural community, should cooperate with the residents, local authorities and officials as well as other actors of the local public scene, convince them of the rightness of what they plan to do, and build alliances and coalitions. The impact of the village representative on local decision-making processes consists of "back-stage" activities, or exerting informal influence over the local government.

\section{Women among village representatives}

Polish women officially acquired the right to run in elections at all levels in the year 1918. However, women living in rural areas were not expected to even take part in village assemblies, as the role of representing the voice of a given family was traditionally ascribed to men (Wawrzykowska-Wierciochowa 1961). The discrepancy between women's formal

4 Since 2009, the municipal councils have had the ability to create a village fund (fundusz sotecki), used to provide financial support for the rural sub-municipal auxiliary units.

5 All persons who are Polish citizens aged 18 years or older, permanent residents of the village, and having all public rights. 
rights and the societal reality was also an aspect in the political institutions at higher levels such as the Polish Parliament (Siemieńska 1990).

According to the existing literature, women were not really present in the structures governing rural sub-municipal auxiliary units neither before the Second World War nor shortly after (Jakubczak 1976). However, the available data indicate a significant and consistently increasing percentage of women among village representatives in Poland during the post-war decades and in recent years. In 1958, the share of women performing this function amounted only to $0.8 \%$; however, in 1967, the percentage reached $2.8 \%$ (Główny Urząd Statystyczny 1968). Currently, at the end of 2015 , the percentage amounts to $39 \%{ }^{6}$

Interestingly, the percentages of women village representatives are visibly higher in the areas added to the Polish territory after the Second World War. Their primary inhabitants were forced to leave shortly after the war or fled before it ended. Afterwards, these territories were settled by people from different parts of pre-war Poland. In this process, new postmigration local communities were created, which, according to the literature, are more willing to accept social innovations, such as women in local power positions, than other communities (cf. Bartkowski 2003). In comparison, the percentages of women village representatives are visibly lower in the southern and eastern regions of Poland, where local communities are characterized by the preserved continuity of traditions (Ibid.). Differences between Polish regions, which historically belonged to different powers after the partitions and territorial redistribution following the Second World War, pertain to many aspects of life, including the degree of urbanization, demographic structure, access to communication infrastructure, voting preferences and economic performance (cf. Nowak et al. 2000; Żukowski 2004).

These observations indicate that analyzing the causes and consequences of feminizing the rural local government is necessary, and the regional differences in the share of women and men among village representatives must be taken into account.

\section{Rural women in politics: literature review}

In the Western European literature, underrepresentation of rural women in politics has particularly been underlined. In the case of rural areas, male domination in politics in general overlaps with male domination in the fields of agriculture, forestry and rural development, which are perceived as "male fields of expertise" (Bock 2010). As a result, rural women are often excluded from decision-making processes regarding policies targeted at the development of rural areas. In EU member states, the situation was not made any better by implementation of new mechanisms and structures for the governing of rural areas, which were supposed to operate from the bottom up and assumed participation of various social actors on the local level (Bock and Derkzen 2008). For instance, the available data show that women are rarely represented equally in Local Action Groups operating in the frame of the LEADER programme (Bock 2010). Gender mainstreaming regarding Common Agricultural Policy and rural development exists only on paper, or is limited to ad

$6 \quad$ Główny Urząd Statystyczny, Local Data Bank (www.stat.gov.pl). 
hoc projects addressed to specific groups of women, and has not led to systemic improvement of the situation of female rural residents or an increase in their participation in political decision-making processes (Shortall 2014; Bock 2014).

The historically and structurally conditioned male domination in politics is maintained by various social and cultural mechanisms. For example, research conducted in the Netherlands indicates the exclusion of women from political decision-making processes by using specific language practices, and underlining the importance of technical and scientific language and depreciating language and knowledge based on experience (Bock and Derkzen 2008). As shown in Little's (1997) work, due to the persistence of traditional gender roles and division into the private and public sphere, in Britain women often fall into the trap of performing informal social activities on behalf of their villages. Altruism is attributed to them as a "natural" concern, and thus they are expected to engage in various voluntary works. Involvement of this kind can be a source of a sense of belonging and of some influence in their communities. However, voluntary work is perceived as "non-professional", "apolitical" and less important than paid work (Little 1997).

As shown, the available literature focuses on the barriers facing rural women who engage in local politics. This paper addresses the other side of the coin - what happens when women are already there: do they behave differently in comparison with their male counterparts?

\section{Gender differences in politics and leadership}

According to the concept of substantive representation, it is assumed that "women politicians prioritize and express different types of values, attitudes, and policy priorities, such as greater concern about childcare, health or education, or a less conflictual and more collaborative political style" (Lovenduski and Norris 2003: 87). Women in politics are more likely to act for women than men, i.e. introduce women's issues into the political agenda (Celis 2008; Celis and Childs 2008; Childs and Krook 2009).

This approach evolved from assuming universal women's interests emerging from the gendered division of labour in the public and private spheres, through claiming that women's interests are not shared by all due to the diversified life experiences of different groups of women, through focusing on specific women's perspectives on political matters resulting from their structural position in society. Therefore, the political representation of women is not about representing universal women's interests or opinions but about introducing women's perspectives on different issues in the political decision making process (Celis 2008). It is worth noting that "women's perspectives" embrace the whole spectrum of political and ideological standpoints, including various feminist and conservative positions (Celis and Childs 2012). Assuming that women are more likely to act for women than men, it is claimed that an increase in the number of female politicians, especially in legislative bodies, will entail a change in political agenda in favour of women's issues (cf. Lovenduski and Norris 2003).

That the relationship between descriptive and substantive representation, i.e. being female and acting for women, is taken for granted resulted in the enormous popularity and 
influence of the concept of "critical mass" (Dahlerup 1988). However, these assumptions, especially as they are not clearly proved with empirical data, have been highly criticized. According to some researchers, the idea of "critical mass" should be replaced by "critical actors": influential women and men, as well as collective and institutional actors, promoting and implementing gender equality issues in both political bodies and beyond (Paxton et al. 2007; Celis and Childs 2008; Childs and Krook 2008).

There are numerous researches in the fields of management and social psychology showing interesting gender differences in terms of organizational leadership. For example, women are more willing to perform a slightly more democratic leadership style than men (Billing and Alvesson 2014: 204). However, it is also possible to quote various studies in which no definite differences were shown in the styles of leadership of women and men in managerial positions (Ibid.). It is assumed that the influence of one's gender could be neutralized due to general norms and practical constraints applying to certain occupational positions concerning appropriate ways to carry out these roles, similar criteria for leadership selection, and possibly, female leaders' dissociation from some feminine qualities (Eagly and Johannesen-Schmidt 2007: 284). Extant research is also criticized for emphasizing the significance of gender differences, which could be counterproductive in terms of advancing gender equality in managerial positions (Billing and Alvesson 2000). However, this does not mean that potential gender differences in professional and political positions should not be studied at all.

\section{Explanations of gender differences: the social role theory and "doing gender" perspec tive}

According to social role theory, gender roles coexist with other specific social roles performed by women and men in private and public settings, like family relationships, occupations or public positions. For example, the role of a manager is defined by the occupation in a given organizational structure, but, at the same time, a woman or man functions as well under the constraints of her or his gender role (Eagly et al. 2012: 154-155).

Basically, gender roles are shared expectations which apply to individuals on the basis of their socially identified sex. They encompass beliefs about what women and men actually do (descriptive norms, synonymous with psychologists' usual definition of stereotypes) and ought to do (injunctive norms), like any other social roles applying to persons who occupy a certain social position or are members of particular social category (Eagly et al. 2012; Eagly and Karau 2002). As Billing and Alvesson state (2000: 153), their creation "is grounded in the division of labour, in the household (including primary caretaking), in the labour market and in organizational practices. Gender is created through women being constructed as mothers and family-oriented, being located in 'female' jobs, in particular service jobs and in subordinated positions". Gender roles translate, through a variety of mediating processes, into real differences in behaviour of women and men (Eagly et al. 2012; Schwartz and Rubel 2005).

Social role theory claims that gender roles - encompassing the agentic focus of the male gender role and the communal focus of the female gender role - exert influence 
on organizational roles, like leadership. Agentic characteristics, which are ascribed more strongly to men, describe primarily an assertive, dominant, controlling, task-oriented and confident tendency. In contrast, communal characteristics, which are ascribed more strongly to women, describe primarily a concern with the well-being of other people. This concern is associated with being helpful, kind, sympathetic, interpersonally sensitive, and supporting others. In consequence, even men and women in similar roles usually enact these roles somewhat differently. These differences are conditioned by pressures from others who have internalized gender roles and expect leaders to behave according to them, as well as by female and male leaders themselves who, to some extent, have internalized these expectations as parts of their identities (Eagly and Karau 2002: 574; Eagly and JohannesenSchmidt 2007: 285).

It is worth emphasizing that gender roles, as well as leadership roles, change over time. Women's average share of university education has for years exceeded that of men (Zimmer and Siemieńska 2003). The modern, professional, career-oriented woman is now a legitimate social identity. In addition, the notion of leadership has changed, becoming more androgynous as culturally feminine relational skills have been strongly recommended (Billing and Alvesson 2014). However, such socio-cultural changes are slow, especially in terms of stereotypes (Eagly and Carli 2003) - women still find it problematic to adopt such career-oriented identities if they break too strongly with traditional ideas of femininity (Billing 2011; Carli and Eagly 2011).

According to the literature, the differences in behaviour between female and male leaders could be explained also by psychological dispositions related to differences in the early childhood socialization of men and women. However, as Poggio (2006: 225) states

in recent decades the traditional essentialist conception of male and female as ascribed individual traits has been superseded and, under the stimulus of constructivist thought and its view of gender as a social product, attention has progressively focused on gendering processes: that is, on how gender is constantly redefined and negotiated in the everyday practices through which individuals interact; how men and women 'do gender' and how they contribute to the construction of gender identities by engaging in a process of reciprocal positioning.

Consequently, the differences in behaviour of male and female managers or political leaders could be explained by using the "doing gender perspective", according to which observed differences have their origin in interaction. Displaying gender in such a way that it meets norms and expectations for being congruent with one's sex (or avoiding such congruency) are reactions to the environment through anticipating other people's evaluations, rather than fixed behaviours or strong norms reinforcing gender stereotypes. For example, women managers could soften their more authoritarian leadership style by incorporating some feminine elements, like expressing concern about the family life of their employees (Billing and Alvesson 2014: 238-241, 246-247). 


\section{Research problem and methodology}

The main aim of this article is to analyze whether women and men differ in performing the role of village representative - do they express differences in leadership style, have different ideas for local initiatives and different ways of cooperating with other local actors? If yes, the question would be how much female and male village representatives differ and how these differences could be appropriately explained?

It is assumed that contextual factors related to particular settings may affect the possible manifestations of gender differences. For example, in male-dominated settings, people are most likely to associate good leadership with stereotypical male traits of agency. Moreover, in masculine settings such as the military, men were rated as more effective leaders than women, whereas in more feminine settings, like social service agencies and schools, women's leadership was perceived as more effective than men's (Carli and Eagly 2011: 111). It is also claimed that people construct their beliefs about the sexes on the basis of observations of the role performances of women and men (Eagly et al. 2012: 124). Therefore, as for the local context's characteristics, different levels of women's participation in local politics will be of special interest.

According to Billing and Alvesson (2014: 240-241), "gender patterns are not so homogenous, fixed, or one-dimensional that a dispositional, structural or interactionist perspective can be expected to explain everything and it is very likely that different dynamics can be put into operation". Most likely there are different subjects, workplaces, interactions, organizations, and times where different perspectives and tendencies are most relevant to consider. It is assumed that identifying the existence of minor or no differences between women and men would emphasize the supremacy of the role of the village representative over gender roles. The role of village representative seems to be quite flexible, and yet strongly embedded in historical tradition shaping it as a male position. The significant differences depending on particular individuals would indicate that, in the case of male and female village representatives, the "doing gender" perspective is the most adequate.

First, the description of interviewed village representatives will be presented. Secondly, the potential significance of the local context for variation in women's presence in local politics will be discussed. Subsequently, the village representatives' leadership styles as well as their initiatives and actions will be characterized. The next section presents the village representatives' modes of cooperating with various local actors.

This article is based on an analysis of qualitative data collected from ten municipalities located in different regions of Poland. Due to the goals of my doctoral dissertation, the municipalities were chosen because of their different proportions of women serving as village representatives and municipal councillors. Two municipalities - "feminized" and "masculinized" - were examined in each of five chosen regions of Poland (Table 1). The former was understood based on the percentage of women among village representatives and municipal councillors, which was close to or over $50 \%$, and the latter represented municipalities where the percentage of women village representatives and municipal councillors did not exceed $30 \%$. 
Table 1: Characteristics of municipalities subject to research (2009)

\begin{tabular}{|c|c|c|c|c|c|c|c|c|c|c|}
\hline \multirow{2}{*}{$\begin{array}{l}\text { Province } \\
\text { Municipality }\end{array}$} & \multicolumn{2}{|c|}{$\begin{array}{l}\text { Zachodniopo- } \\
\text { morskie }\end{array}$} & \multicolumn{2}{|c|}{ Mazowieckie } & \multicolumn{2}{|c|}{ Lubelskie } & \multicolumn{2}{|c|}{ Wielkopolskie } & \multicolumn{2}{|c|}{ Podkarpackie } \\
\hline & $\begin{array}{l}\text { Dobra } \\
\text { Szcze- } \\
\text { cińska }\end{array}$ & Mielno & $\begin{array}{c}\text { Kałus- } \\
\text { zyn }\end{array}$ & $\begin{array}{c}\text { Wys- } \\
\text { zogród }\end{array}$ & Serniki & Ryki & $\begin{array}{l}\text { Muro- } \\
\text { wana } \\
\text { Goślina }\end{array}$ & $\begin{array}{l}\text { Czer- } \\
\text { wonak }\end{array}$ & $\begin{array}{l}\text { Luto- } \\
\text { wiska }\end{array}$ & tańcut \\
\hline Type & nural & rural & $\begin{array}{l}\text { urban- } \\
\text { rural }\end{array}$ & $\begin{array}{l}\text { urban- } \\
\text { nural }\end{array}$ & nural & $\begin{array}{l}\text { urban- } \\
\text { nural }\end{array}$ & $\begin{array}{l}\text { urban- } \\
\text { rural }\end{array}$ & nural & rural & nural \\
\hline Population & 15,569 & 4,935 & 6,086 & 5,939 & 4,876 & 20,505 & 16,248 & 25,300 & 2,195 & 20,849 \\
\hline $\begin{array}{l}\text { Share of women } \\
\text { among municipal } \\
\text { councillors }\end{array}$ & 53.3 & 33.3 & 53.3 & 6.7 & 40.0 & 19.0 & 53.3 & 28.6 & 13.3 & 9.5 \\
\hline $\begin{array}{l}\text { Share of women } \\
\text { among village } \\
\text { representatives }\end{array}$ & 66.7 & 12.5 & 75.0 & 11.8 & 46.2 & 23.3 & 25.0 & 36.4 & 66.7 & 11.1 \\
\hline
\end{tabular}

Source: Główny Urząd Statystyczny, Local Data Bank

Fieldwork was completed between November 2009 and December 2010. In total, 108 in-depth individual interviews were conducted in ten municipalities. The respondents consisted of 51 village representatives and 57 interviewees from local authorities, public institutions and organizations. Among the village representatives interviewed were 28 women and 23 men. The remaining interviewees consisted of 34 women and 23 men: representatives of municipal authorities (mayors, councillors) and leaders of local organisations, as well as local public officers.

\section{Description of inteniewed village representatives}

Most interviewees had performed the function of a village representative for one, two or, less often, three four-year terms of office. Furthermore, women represented a large number of those who had served for one or two terms of office, whereas the group of those with more experience was slightly dominated by men.

The age structure of female and male respondents also revealed some differences; women prevailed in the "younger" age categories (between 31 and 40 years). However, both women and men village representatives were mostly between 41 and 70 years of age. A large number of female village representatives had completed vocational secondary education, whereas most of the male respondents had completed up to vocational secondary and a basic vocational level of education.

Moreover, many of the respondents serving as the village representative were farmers or beneficiaries of old-age or disability pensions. Thus, they were able to manage their time more flexibly than people employed outside the agricultural sector, spending most of their time at their place of residence. This is of significance when taking into account the typical tasks of village representatives described earlier. 


\section{Local context and gender roles}

Interestingly enough, gender roles in the private and public spheres were depicted somehow differently by female and male interviewees in "feminized" and "masculinized" municipalities. As for the gender roles in the private sphere, the respondents in the "feminized" municipalities pointed out changes in the general way of thinking about the equality of men and women: "It seems to me that the social awareness has increased... women no longer fit this stereotype of only taking care of the house, children, cleaning, cooking" [L.S.8_f.l]"; "Everywhere, in every aspect of life, I think, women are taking initiative very strongly" [Z.D.9_f.v]. In the "masculinized" municipalities, most respondents, including women, tended to declare that women were not interested in public positions because they focused on the home and family: "With regards to female village representatives, for ages women have not been allowed to participate in power, only hearth and home. A guy was more to attend to everything, representing outside of home and outside of the village" [M.W.8_f.c]. Some respondents even referred to the laziness of local women, suggesting that they spend their time mostly in front of the TV, as well as having a fear of failure, which prevents them from achieving social commitment. Particularly in the "masculinized" municipalities, local politics was perceived as the domain of men, and social and cultural work was that of women: "Perhaps this patriarchal model is rooted so deeply here that 'it is always up to men to rule'... as for social work, cultural work... it's mostly women" [P.Ł.5_m.o].

Women engaged in local politics (e.g. as village representatives and municipal council members) have often been assigned characteristics which are stereotypically associated with women: calmness, composure, sense of responsibility, discipline and scrupulousness in performance of tasks. Interestingly, in the "feminized" municipalities, in which there were more women among the village representatives and municipal council members, both men and women assessed these features very positively - as being necessary for engagement in the local government: "First of all, they are more determined, willing to defend their cause, they are very good partners in cooperation" [M.K.9_m.c]. In the "masculinized" municipalities, on the other hand, most of these features were referred to as "weaknesses", since involvement in the local government often requires determination or the ability to enforce one's point of view. In the "feminized" municipalities it was also pointed out that women brought new qualities into the local politics: "they are more committed, more willing to cooperate. And men tend to go their own ways. Unless they're party members already... and they know there are benefits in it. Women are more focused on cooperation, on giving" [Z.D.6_f.c]. Women serving as village representatives and municipal councillors in "masculinized" municipalities experienced a sense of uncertainty and perceived themselves

Marking of interviews: the first letter means the province $(\mathrm{Z}=$ Zachodniopomorskie, $\mathrm{M}=$ Mazowieckie, $\mathrm{L}=$ Lubelskie, $\mathrm{W}=$ Wielkopolskie, $\mathrm{P}=$ Podkarpackie), the second letter refers to the first letter(s) in the name of the municipality, letters " $\mathrm{f}$ " or " $\mathrm{m}$ " refer to the respondent being female or male, the last letters indicate the category of the respondent - "v" means village representative, "l" means local leader, "c" means municipal councillor and "o" means public official or a representative of another local institution. 
as outsiders. For many, the sense of isolation was associated with the classic situation of being excluded from male social networks.

\section{Village representatives' leadership style}

While characterizing their modes of cooperation with the village residents, most village representatives interviewed, both women and men, emphasized similar aspects of leadership.

First of all, the interviewees pointed out the importance of the ability to withdraw from excessive exposure of the village representative's own role in a given initiative. This is illustrated very well by the statement of one of the interviewed female village representatives: "I don't do this for myself... I always do it 'for us - by us'. I never say 'I did' or 'I want to'... even if I'm doing something on my own... I never [say] I did this... but I say it was done by the [village] council, or by the residents of the village" [Z.D.10_f.v]. According to the interviewees, a village representative should never demand anything from the residents, but rather ask for their help and support.

Secondly, the leadership of the village representative should be "fair", meaning that it is necessary to care for even distribution of involvement of individual persons or groups: "Parents, who have children at school. They are divided. It can't be done in any other way, because it's not going to be like, one of them, seven times, and another one, not even once" [L.S.3_f.v].

Thirdly, the residents want to see the personal, genuine involvement of the village representative in a given undertaking, as well as readiness to dedicate her or his own resources, for instance, her or his own funds: "I also gave a lot of my own money. And the people can see that" [P.L.12_m.v].

Fourthly, it is also necessary to provide a certain way of thanking the residents for their involvement, which demonstrates appreciation for their work. Some of the respondents attempt to do it in public, for instance, during the parish announcements at the local church.

Both women and men underlined that a prerequisite for effective mobilization of the inhabitants to cooperate was direct communication - frequent and regular talks with the residents of the village: "I speak to them a lot, even when I collect those taxes - because I am a tax agent, too - so, I go to every home. Sometimes the day's simply too short. Everyone would like to talk to me, about this, about that - well, there's lots of things to discuss" [P.L.12_m.v]. The readiness of the village representative to dedicate her or his time for direct, "slow" chats with the residents strengthens the mutual trust. The people must feel that they are unique and appreciated to be willing to assume a part of responsibility for the tasks completed.

It should be underlined, however, that women village representatives much more often than men described themselves as ready to work patiently on their relations with the residents. The people are able to "sense" the genuineness of such an attitude and are eager to talk not only about the affairs of the village, but about their problems in life as well: "It is just that this role [of the village representative] is very needed, because sometimes you just have to listen to them, because something happened, and you have prick up one's ears and be a psychologist" [Z.D.9_f.v]. Women also seem to be more inclined to talk with residents, 
explain their plans, and invite cooperation: "I just visit people, talk to them, I ask them to take part, to contribute" [P.L.3_f.v].

The men in the study also thought that convincing residents directly is the best method for mobilizing them. It should be noted, however, that in the statements of the male village representatives, this was often accompanied by some discouragement; they seemed tired of the necessity of having to convince others all the time: "It is not that you come once and once you say it and it is done, you have to remind, telephone, ask, go" [W.MG.5_m.v]. Some of them claimed that "it was not worth it", and local initiatives could be completed easier on their own or with small groups of reliable persons.

The leadership style described by women and men among the interviewed village representatives is similar to the notion of servant leadership, which is characterized in the literature by: listening, empathy, healing, awareness, persuasion, conceptualization, foresight, stewardship, commitment, demonstrating appreciation of others' service, and building community (Avolio et al. 2009: 436-437). However, the women described themselves as relatively more willing to act according to this style as men.

\section{Types of local initiatives undertaken by female and male village representatives}

Despite the diversity of rural milieus from which the interviewees came, their statements concerning the obligations of the village representative turned out to be rather consistent. Most often, they referred to the village representative as a "liaison" between the inhabitants of the village and the local authorities at the higher level. A decisive majority also spoke of responding to the current problems and needs of the inhabitants. The duties of the village representative included making efforts to improve the condition of the local "technical" infrastructure (roads, sewage and water-supply systems, gas network, internet network, etc.), "social" infrastructure and improving the quality of the public space (rural community centres, playgrounds, sports fields, the village centres, caretaking, and village aesthetics). Other types of activities mentioned by the interviewees included residents' integrationbuilding initiatives (fairs, local festivals, special occasion parties) as well as charitable actions (e.g. food collections, help to the elderly and disabled). It seems that both women and men village representatives tried to address the most urgent needs in a given locality.

However, an in-depth analysis of the interviews allowed me to capture some interesting differences. Men were more focused on the improvement of the local road infrastructure, sewage, etc., while women more often tended to prioritize enlivening the local social life. The latter found integration and public spaces building initiatives (rural community centres, fairgrounds, etc.) especially important. Men also took on such activities, but they tended to list them further on, giving more focus in their interviews to solving problems regarding local "technical" infrastructure. They did not pay as much attention as women to the social, integrative functions of a well-managed and maintained local public space. The female village representatives, more often than men, referred to making the local public space "beautiful" or "decorating" it, for instance, by planting flowers or bushes. The male village representatives referred rather to "cleaning" of space and the associated manual labour. Also, 
it occurred that only female village representatives organized philanthropic and charitable initiatives, like visiting the elderly and lonely during Christmas, or helping people in difficult circumstances: "It was nice, when Santa Claus knocked on the doors of the elderly lonely lady, brought her a package... My neighbour made an outfit, and we went" [Z.D.9_f.v]; "[our village representative] is very much interested in victims of various unfortunate events, and the poor... there's always some assistance organized for these people, by the church or just the neighbours..." [Z.D.2_f.l]. The several men in the study also got involved in such initiatives, but rarely did they organize them.

The most interesting and innovative activities were mentioned by women village representatives from the "feminized" municipalities. They pointed to the need for organization of social space in the village in a "pro-community" way, so that various groups of inhabitants, including mothers with small children and the elderly, could spend their free time there safely and nicely. The list of examples included cleaning of the local park: "Last year, we opened this park, there are benches there, you can sit down. Even with the children, the mothers meet there, and this is really something nice" [Z.D.1_f.v]. In another municipality, a similar concept led to cleaning of the local pond: "There was this idea of making a playground for children... there are mums, and they have nowhere to go, etc... This was an initiative of women, who somehow started to act in this [municipal] council" [L.S.7_f.c]. The other examples include interesting initiatives aimed at integration of the residents, such as a "flea market" for the inhabitants (exchange of used clothes and items) and fitness classes for the local women.

\section{Village representatives' cooperation with other loc al actors}

The interviewed village representatives most often declared cooperation with municipal authorities, members of their village councils, local social organizations and public institutions, as well as neighbours, friends and relatives (see Table 2). It is worth noting that their networks of local cooperation seemed to be "gendered": women and men indicated slightly different types of actors with whom they work.

However, all the village representatives interviewed put particular emphasis on their cooperation with municipal council members representing the electoral districts in which their village is located. They have higher potential of enforcement of local affairs during the municipal council sessions and committee meetings, as they have the right to vote. Some of the interviewees indicated that effective cooperation, when it is satisfactory to both parties, may lead to shaping of long-term strategic "alliances" between village representatives and "their" municipal council members. Women referred in this context to "cooperation" understood broadly, while men tended more often described specific "strategies". One of the male village representatives decided not to participate in the local elections, because he did not want to compete with "his" municipal council member. This may indicate the men's better familiarity with the rules of the local "political games", and their ability to take advantage of these rules to achieve their objectives.

Another significant actors of cooperation for the female and male village representatives were local organizations, particularly "traditional" ones (such as voluntary fire services, 
rural women's organizations, and sports clubs). In the case of some of the interviewees (the number of men among them being slightly higher), mobilization of resources of this kind in local cooperation is partially due to their own involvement in a given organization. At the same time, it was rather the female than male village representatives who referred to themselves as having established the local organizations in their villages: the "Caritas" branch $^{8}$ (one female representative), village associations (one male and four female representatives), the voluntary fire service (one female and one male representative). For the sake of comparison, male village representatives (seven of them) more often than females (two) indicated that the local organizations established during their term of office were a result of the initiative of other local actors - e.g. teachers and parents, "newcomers" from the city, council members and local leaders.

Table 2: Cooperation partners of the women and men village representatives interviewed

\begin{tabular}{|c|c|c|c|}
\hline Cooperation partners & Women $(\mathrm{N}=28)$ & Men $(\mathrm{N}=23)$ & Total $(\mathrm{N}=51)$ \\
\hline Local a uthorities, munic ipa lity level & 23 & 18 & 41 \\
\hline Village council & 10 & 7 & 17 \\
\hline Traditional rural local orga niza tions & 8 & 8 & 16 \\
\hline $\begin{array}{l}\text { Local institutions (community center, } \\
\text { library, local public administration office, } \\
\text { cultural center etc.) }\end{array}$ & 7 & 4 & 11 \\
\hline Friends and neighbours & 7 & 4 & 11 \\
\hline NGOs (associations) & 3 & 6 & 9 \\
\hline School, parent committee & 6 & 3 & 9 \\
\hline Priest, parish council & 3 & 5 & 8 \\
\hline Other village representatives & 5 & 2 & 7 \\
\hline Local entrepreneurs & 3 & 4 & 7 \\
\hline Fa mily members & 4 & 2 & 6 \\
\hline Local a uthorities above munic ipality level & 2 & 2 & 4 \\
\hline Politic al party & - & 2 & 2 \\
\hline Other* & 2 & 3 & 5 \\
\hline
\end{tabular}

Note: The respondents usually indicated several types of partners for cooperation.

*Hunting association, Polish Tourist and Sightseeing Society (PTTK), Mountain Volunteer Search and Rescue (GOPR), border guards, forestry employees.

Cooperation with neighbours and friends was indicated slightly more often by female than male village representatives. It should be noted that cooperation was emphasized in particular by interviewees in those communities which lacked active local organizations. Some interviewees, mostly women, underlined the significance of support from their close relatives in acting on behalf of the village: their spouse, children or parents.

8 "Caritas" is a confederation of Catholic charities, development and social service organisations operating in over 200 countries and territories worldwide. 


\section{Conclusion}

Interestingly, the social perception of gender roles in the private and public spheres turned out to be different in the "feminized" and "masculinized" municipalities. In the former, redefinition of gender roles was indicated more often than in the latter. References were made to the fact of women going visibly beyond their "traditional" duties, associated with family life and running of the household. Female village representatives and municipal council members were perceived as being competent and well prepared for the performance of these roles. In the "masculinized" municipalities, opinions about gender roles and women's engagement in the local public sphere were rather different. It can thus be said that women, particularly in public roles, are subject to strong stereotypization, which is either positive or negative, depending on their higher or lower involvement in local politics and the structures of local government.

Most of the interviewed women and men village representatives characterized their leadership style in terms of servant leadership. The gender differences identified are minor - women described themselves as more oriented towards convincing fellow residents to accept their point of view and to provide them with emotional support when needed. The types of local initiatives being implemented turned out to be quite similar for both women and men. However, the women more often assumed a "community" perspective, in which the integration of the village residents was a priority. In addition, only women initiated various charity and assistance events addressed to the elderly and the lonely, as well as persons facing difficult life situations. The examples of innovative initiatives were identified in the narratives of women village representatives from "feminized" municipalities. As for cooperation with other local actors, female village representatives, slightly more often than men, based their networks of cooperation on informal relations within the framework of family or neighbourhood structures.

Such minor gender differences between women and men village representatives indicate that social role theory is the most adequate way of explaining them. Regardless of the fact that the responsibilities of village representatives are not really described by law, there is a strong historic tradition of village representatives voicing residents' interests and concerns, as well as reacting to the most urgent problems and needs in a given village. Therefore, the main types of initiatives and the leadership styles of the interviewed women and men village representatives are quite similar. However, the influence of gender roles is also visible - willingness to care for vulnerable ones and building quasi-intimate relationships with the residents, as well as a sensitivity for the aesthetics of local public space, are clearly characteristics culturally ascribed to women. This is consistent with the claims of Eagly et al. (2012) that more specific social roles tend to influence people's behaviour to a greater extent than more general gender roles - i.e. gender differences become less visible when comparing men and women who occupy the same specific role.

Interestingly, the women village representatives most innovative in terms of their activities were interviewed in the "feminized" municipalities. Possibly, the greater women's presence in local politics resulted in the greater congruity between gender roles and a village representative role perceived in the local setting with women serving as "public actors" as the norm. Therefore, women village representatives are perhaps more confident 
in following their ideas in this context. However, local differences in defining gender roles and the way in which local perceptions of gender roles translate (or not) into different behaviours of women and men in the public and private spheres should be the subject of another, in-depth investigation. Probably, more factors should be taken into account in such research, such as the personal approval of traditional versus non-traditional definitions of gender roles expressed by women and men in political and leadership positions, as well as their family situation. In addition, the broader cultural and social context should be included, i.e. the dominant trends in defining gender roles in a given society and/or region of the country. Systematic research on the different factors which may affect the interplay between gender roles and particular leadership roles would contribute to the further development of social roles theory and its adaptation to the complexity of modern realities.

\section{References}

APPELBAUM, Steven H., Lynda AUDET and Joanne C. MILLER. 2003. "Gender and Leadership? Leadership and Gender? A Journey Through the Landscape of Theories." Leadership \& Organizational Development Journal 24(1): 43-51.

AVOLIO, Bruce J., Fred O. WALUMBWA and Todd J. WEBER. 2009. "Leadership: Current Theories, Research, and Future Directions." Annual Review of Psychology 60: 421-449.

BARTKOWSKI, Jerzy. 2003. Tradycja i polityka: Wpływ tradycji kulturowych polskich regionów na wspótczesne zachowania społeczne i polityczne [Tradition and Politics: The Influence of Cultural Traditions of Polish Regions on Contemporary Social and Political Behaviour]. Warsaw: "Żak".

BILLING, Yvonne Due. 2011. "Are Women in Management Victims of the Phantom of the Male Norm?" Gender, Work and Organization 18(3): 298-317.

BILLING, Yvonne Due and Mats ALVESSON. 2000. "Questioning the Notion of Feminine Leadership: A Critical Perspective on the Gender Labeling of Leadership." Gender, Work and Organization 7(3): 144-157.

BILLING, Yvonne Due and Mats ALVESSON. 2014. "Leadership: A Matter of Gender?” Pp. 200-223 in The Oxford Handbook of Gender in Organizations, edited by Savita KUMRA, Ruth SIMPSON and Ronald J. BURKE. Oxford: Oxford University Press.

BOCK, Bettina. 2010. Personal and Social Development of Women in Rural Areas in Europe. Brussels: European Parliament.

BOCK, Bettina. 2014. "Gender Mainstreaming and Rural Development Policy: The Trivialization of Rural Gender Issues." Gender, Place and Culture: A Journal of Feminist Geography 22(5): 731-745.

BOCK, Bettina and Petra DERKZEN. 2008. "Barriers to Women's Participation in Rural Policy Making". Pp. 263-281 in Gender Regimes, Citizen Participation and Rural Restructuring, edited by Ildikó A. MORELL and Bettina BOCK. Amsterdam: Elsevier.

CARLI, Linda L. and Alice H. EAGLY. 2011. "Gender and Leadership.” Pp. 103-117 in The SAGE Handbook of Leadership, edited by Alan BRYMAN, David COLLINSON, Keith GRINT, Brad JACKSON and Mary UHL-BIEN. London: SAGE.

CELIS, Karen. 2008. "Studying Women's Substantive Representation in Legislatures: When Representative Acts, Contexts and Women's Interests Become Important.” Representation 44(2): 111-123.

CELIS, Karen and Sarah CHILDS. 2008. "Introduction: The Descriptive and Substantive Representation of Women: New Directions." Parliamentary Affairs 61(3): 419-425. 
CELIS, Karen and Sarah CHILDS. 2012. "The Substantive Representation of Women: What to Do with Conservative Claims?" Political Studies 60: 213-225.

CHILDS, Sarah and Mona L. KROOK. 2009. “Analysing Women's Substantive Representation: From Critical Mass to Critical Actors." Government and Opposition 44(2): 125-145.

DAHLERUP, Drude. 1988. "From a Small to a Large Minority: Women in Scandinavian Politics." Scandinavian Political Studies 11(4): 275-298.

EAGLY, Alice H. and Steven J. KARAU. 2002. "Role Congruity Theory of Prejudice Toward Female Leaders." Psychological Review 109(3): 573-598.

EAGLY, Alice H., Mary C. JOHANNESEN-SCHMIDT and Marloes L. van ENGEN. 2003. "Transformational, Transactional, and Laissez-Faire Leadership Styles: A Meta-Analysis Comparing Women and Men.” Psychological Bulletin 129(4): 569-591.

EAGLY, Alice H. and Mary C. JOHANNESEN-SCHMIDT. 2007. "Leadership Style Matters: The Small but Important, Style Differences between Male and Female Leaders.” Pp. 279-303 in Handbook on Women in Business and Management, edited by Diana BILIMORIA and Sandy K. PIDERIT. Chetlenham: Edward Elgar Publishing.

EAGLY, Alice H., Wendy WOOD and Amanda B. DIEKMAN. 2012. "Social Role Theory of Sex Differences and Similarities: A Current Appraisal." Pp. 123-170 in The Developmental Social Psychology of Gender, edited by Thomas ECKES and Hanns M. TRAUTNER. New York: Taylor \& Francis Group Psychology Press.

GŁÓWNY URZĄD STATYSTYCZNY [CENTRAL STATISTICAL OFFICE]. 1968. Solectwa $i$ soltysi [Rural Sub-municipal Auxiliary Units and Village Representatives]. Warsaw: GUS.

JAKUBCZAK, Franciszek, ed. 1976. Być w środku życia [Being at the Centre of Life]. Warsaw: "Książka i Wiedza".

LITTLE, Jo. 1997. "Constructions of Rural Women's Voluntary Work." Gender, Place and Culture: A Journal of Feminist Geography 4(2): 197-210.

LOVENDUSKI, Joni and Pippa NORRIS. 2003. "Westminster Women: The Politics of Presence." Political Studies 51: 84-102.

MATYSIAK, Ilona. 2014. Rola sołtysów we współczesnych społecznościach wiejskich. Płeć jako czynnik różnicujący kapitat społeczny [The Role of Village Representatives in Contemporary Rural Communities. Gender as a Factor Influencing Differences in Social Capital]. Warsaw: Wydawnictwo Naukowe Scholar.

NOWAK, Andrzej, Marek KUŚ, Jakub URBANIAK and Tomasz ZARYCKI. 2000. "Stimulating the Coordination of Individual Economic Decisions." Physica A 287: 613-630.

PAXTON, Pamela, Sheri KUNOVICH and Melanie M. HUGHES. 2007. "Gender in Politics.” Annual Review of Sociology 33: 263-284.

POGGIO, Barbara. 2006. "Editorial: Outline of a Theory of Gender Practices." Gender, Work and Organization 13(3): 225-233.

SCHWARTZ, Shalom H. and Tammy RUBEL. 2005. "Sex Differences in Value Priorities: Cross-Cultural and Multimethod Studies." Journal of Personality and Social Psychology 89(6): 1010-1028.

SHORTALL, Sally. 2014. "Gender Mainstreaming and the Common Agricultural Policy." Gender, Place and Culture: A Journal of Feminist Geography 22(5): 717-730.

SIEMIEŃSKA, Renata. 1990. Płeć, zawód, polityka: Kobiety w życiu publicznym w Polsce [Gender, Profession, Politics: Women in Public Life in Poland]. Warsaw: Uniwersytet Warszawski, Instytut Socjologii.

WAWRZYKOWSKA-WIERCIOCHOWA, Dionizja. 1961. Z dziejów kobiety wiejskiej: Szkice historyczne 1861-1945 [History of Rural Women: Historical Sketches 1861-1945]. Warsaw: Ludowa Spółdzielnia Wydawnicza. 
ZIMMER, Annette and Renata SIEMIEŃSKA (eds.). 2003. Gendered Trajectories in Academia in CrossNational Perspective. Warsaw: Wydawnictwo Naukowe Scholar.

ŻUKOWSKI, Ryszard. 2004. "Historical Path Dependence, Institutional Persistence, and Transition to Market Economy: The Case of Poland." International Journal of Social Economics 31(10): 955-973.

\section{Author}

Ilona Matysiak is a sociologist and assistant professor at the Institute of Philosophy and Sociology at Maria Grzegorzewska University in Warsaw, Poland.

Contact: imatysiak@aps.edu.pl 